\title{
The Lens to See the Construction of Organizational Identities: A Discursive Framework of Shanghai Disneyland
}

\author{
Zhaowei $\mathrm{Li}^{1} \&$ Fang Guo ${ }^{1}$ \\ ${ }^{1}$ School of Foreign Languages, North China Electric Power University, Beijing, China \\ Correspondence: Zhaowei Li, School of Foreign Languages, North China Electric Power University, Beijing, \\ China. E-mail: 1738111299@qq.com
}

Received: December 22, 2020

Accepted: January 23, $2021 \quad$ Online Published: January 30, 2021

doi:10.5539/ijel.v11n1p300

URL: https://doi.org/10.5539/ijel.v11n1p300

\begin{abstract}
The importance of organizational identity has aroused many people's interest. This study not only emphasizes on identity types and their analysis process but also focuses on the philosophical concern and relations between different fields. The key point for this identity investigation is the integration of different disciplines. This study will show that people can benefit from knowing the mechanism of image formation and adaptation. Findings also suggest that we should open our mind to deepen some academic research.
\end{abstract}

Keywords: organizational identity, discourse analysis, business expansion, integrative model, Shanghai Disneyland

\section{Introduction}

Identity is a hot topic in the study of arts and humanities which has drawn many attentions in linguistics and other fields over the past 50 years. The reason why so many scholars choose identity to study is based on its rich connotation and strong explanatory power. There are two main camps in history about identity research: essentialism and constructionism. Essentialism holds the view that identities are born with and they are constant and unchangeable. But constructionism challenged this view and put forward that everything include identity is constructed by the social practice of people and identity is not fixed but dynamic.

As the organization began to enter people's eyesight, the investigation of the organization as become a hotbed for academic research in the past decade. It is commonly argued that organization identity represents the form by which organizational members define themselves as a social group concerning their external environment, and how they understand themselves to be different from their competitors (Dutton et al., 1994). Although there is some progress in organizational identity studies like relevant research about hospitals and universities, the exploration about identity construction is under-investigated and the integration with other field is far from enough. We assert that the infusion between different research disciplines is useful which needs to be given some thoughts.

\section{The Linguistic Approach to Organizational Identity}

Identity is first of philosophical origin which can be traced back to Greek tradition. In the latter part of the last century, the research on identity construction from the perspective of linguistics has gathered much wisdom of scholars. Linguistics is a study whose focus is on language. Language is an important way to express the meaning of identity and it is a suitable door to unveil the mystery of identity. The mechanism guiding the forming of identity can be explored through a detailed explanation of texts or discourses. The close relationship between image and language has been emphasized and frequently discussed. Our study will be a linguistic based study. In Fairclough's words, the discursive practice can be understood as a kind of smaller social practice that includes the production and understanding of texts (1992). So in certain sense, organizations are socially constructed and to some degrees they are the outcome of discursive practice.

The production of language has some goals to achieve and naturally, we should put texts in context. To thoroughly know the governing system of discursive construction about organizational identity, the context in which discursive practice happens should and must be taken into consideration. No one lives alone, also organizations do not exist in isolation. Everything is in touch with others in a complicated and subtle way. The reasons why varying identities are created verbally or written depends on context, in other words, the decisive 
factors like social field, the situational setting or the topic. The analysis of organizational identity can help us know how the organization interacts with the world. The analytical focus will therefore lie on how discourse is related to other social elements (Chouliaraki \& Fairclough, 2010).

\section{The Integrative Model of Organizational Identity Construction for Shanghai Disneyland in the Wake of Business Expansion}

Social structure is background that determines the identities organizations want to show in front of the public. An organization exists in society which naturally determines that it has certain roles to play. To make profits is sustainably a major intention for most organizations, which is their business aspect. The environment determines the way the organization shows itself in public which cannot be chosen at random. Organizations must maintain an enduring identity while remaining profitable by constantly using an adaptive identity to adjust to the changing environment. Identity construction is an on-going process.

The synergies between business and organization studies are something that is helpful for our study. The dialogue between different disciplines is necessary. A trans-disciplinary approach incorporates business and discursive construction of organizational identity.

We will adopt a case study design because our study is exploratory rather than confirmatory. With the development of the world economy, people have a large enthusiasm for tourist products. Theme parks are a relatively new form of leisure attractions that create a fantastic atmosphere of another place and time (Milman, Li, Wang, \& Yu, 2012). On June 16, 2016, the world's sixth Disneyland opened in Shanghai. It can be deducted that what factors are included in the actors' minds to form its online discourse. Shanghai Disneyland is a popular destination for many tourists. But facing with varying circumstances, Shanghai Disneyland must be flexible and wise to let what it does make sense. To keep it sustainable, Shanghai Disneyland must adjust accordingly to gain long-term success. We need to explore deeply about discursive strategies which mean to enhance its brand image.

\section{The Discursive Strategies of Shanghai Disneyland on its WeChat's Official Account}

Critical Discourse Analysis perceives both written and spoken 'discourse' as a form of social practice (Fairclough \& Wodak, 1997; Wodak, 1995, 1996). Discourse is a kind of social practice which can change things in society, having certain influence to people relevant. If people want to go to hospital, travel to a beautiful place or buy some goods, they will act accordingly and the actions they take are social practices which happen in society. In other words, language was designed for people to communicate to others to let the information flow easily. But as things change and social civilization develops, language has an exquisite mechanism which governs our thinking towards things. If people know the mechanisms perfectly, they can easily control people's thoughts and achieve their purpose. The purpose either is to sell their products or services, or have a better relationship with others. In some senses, they compose a type of power which decides the direction of our life. Naturally, linguists focus their study on language, emphasizing the importance of texts or discourses.

Here, we use Wodak's way to conduct our research. The discourse-historical analysis method of Wodak concentrates on the way discourse reflects social structure and how social structure influences the order and contents of discourse. One of Wodak's analysis dimension is contents or topics. topics or contents are what a discourse is mainly talking about. All words are arranged centered on topics. Our data all come from WeChat. We choose titles and contents of Shanghai Disneyland on its official account as our research body. The headlines are the most distinguished part in readers' eyes. The basic analysis units are lexical words. The expressions and the way it organize its contents can affect the actual identification of Shanghai Disneyland for viewers. We will use qualitative analysis because our study needs elaborateness.

We found that there are titles which have movie names or movie characters like Frozen, Monster University, Inside Out, Coco and Mulan. As a symbol of American culture, most Disneyland tourists do not just go there to play entertainment facilities. Most of the consumers want to feel the characters in Disney movies and experience the unique culture. Example 1 and 2 will show that social actors build Shanghai Disneyland as an organization that culture is its unique selling point.

Example 1: 一场视听盛宴准备就绪, 一幕接着一幕的经典迪斯尼故事, 栩栩如生地浮现在眼前: 清澈的 莲花 别致的凉亭、还有骏马, 就在熟悉的场景与燃情的旋律中, 尽情沉浸于木兰的世界。(An audio-visual feast is ready. Scene after scene of classic Disney stories vividly emerge in front of us: the clear lotus, the unique Pavilion, and the horse immersing yourself in the world of Mulan in the familiar scenes and passionate melody.)

Example 2: 心爱的艾莎和安娜, 一起欢唱吧, 当迪斯尼的魔法降临, 沉浸式体验音乐与魔法的神奇鬼力。 (Beloved Aisha and Anna will sing together. When the magic of Disney comes, we can immerse ourselves in the 
magic of music and magic.)

We know that Disneyland is from the United States and when it comes to Shanghai, it must change some of its characteristics to become suitable for visitors in China. Disneyland has its native country's style. The applicability is a difficult and necessary problem to tackle with. In China, food is very important for people, so catering is an indispensable step in Disneyland's localization. After the opening of the park, many of the restaurants in the park are Chinese food like Shanghai fresh meat pie, pork dumplings and pearl milk tea which show on its WeChat's official account. The high coverage of Chinese food fully reflects Disneyland's attention shift to Chinese people's eating habits. All those make us get the conclusion that Shanghai Disneyland is an organization that is aware of localization.

Shanghai Disneyland constantly enriches its industrial chain, integrates into consumers' life from the aspects of finance, transportation, consumption, etc., and establishes emotional stickiness with users by brand image. The functions can be retail practices, let visitors pay price premiums making consumers revisit. Children are a big consumer group and so its target is to raise children's desire and what it conveys must appeal to children. It shows a friendly image on its official accounts. Under the pressure of business expansion, all that organization members do on their WeChat's official account is mainly to raise visitor attendance and make profits. The organizational identities it constructs are that Shanghai Disneyland is profit-driven and considerate as Example 3 to 7 demonstrate.

Example 3: 现在加入年卡大家庭, 畅玩圣诞季! (Now join the annual card family and happily enjoy the Christmas season!)

Example 4:【年会奇妙套餐】50 人以上有惊喜, 欢迎来上海迪斯尼包场开年。 (Wonderful Package of Annual Party: the group having more than 50 people will have a surprise. Welcome to Shanghai Disneyland to hold the annual party.)

Example 5: 当迪斯尼朋友遇到传统二十四节气, 爱了爱了。(When Disney friends meet the traditional 24 solar terms, we will love it very much.)

Example 6: 探险队长将带领宝贝们用望远镜寻找水鸟和林鸟, 在游戏中培养宝贝们敏锐的观察力。(The expedition team leader will lead the children to look for waterbirds and woodbirds with binoculars to cultivate their keen observation ability in the game.)

Example 7: 乐园设有童车租赁, 解放双手轻松代步。(The park has service of children's car rental, which will free your hands when walking.)

Identities are multi-dimensional, layered, and dynamic (De Fina et al., 2006). From its organizational identities constructed on its WeChat's official account, we see that Shanghai Disneyland shows a positive and popular image. It says that the organization pays great attention to the visitor's experiences. In the context it creates, it puts tourist experience on their list and aims to provide a creative experience for them.

\section{Conclusions}

In short summary, relying on the dominant advantage of content, Shanghai Disneyland has made a brilliant combination of business and discourse study, highly integrating high-quality resources and comprehensively enhancing the power of communication.

And it will provide a good example for the theme-park industry, and other tourism industries. The insights from our research will enlighten practitioners to adopt our findings and apply them in their practice. For the sake of development, identity creation is a task that people should master to better their organization's image.

Also, our findings have managerial implications and they can be put into operation. It provides a detailed means. People need to explore what identities it should show on its WeChat's official account or other channels so that they can make a good advantage. The combination of different disciplines deserves our thinking. As for the methodological consideration, this model will be useful for other organization studies using the discourse-analytical tools.

\section{References}

Chouliaraki, L., \& Fairclough, N. (2010). Critical discourse analysis in organizational studies: Towards an integrationist methodology. Journal of Management Studies, 47, 1213-1218. https://doi.org/10.1111/j.1467-6486.2009.00883.x

De Fina, A., Schiffrin, D., \& Bamberg, M. (2006). Discourse and Identity. Cambridge, UK: Cambridge University Press. https://doi.org/10.1017/CBO9780511584459 
Dennis, A. G., Majken, S., \& Kevin, G. C. (2000). Organizational identity, image, and adaptive instability. Academy Management of Review, 25(1), 63-81. https://doi.org/10.5465/amr.2000.2791603

Dutton, J., Dukerich, J., \& Harquail, C. (1994). Organizational images and member identification. Administrative Science Quarterly, 39, 239-263. https://doi.org/10.2307/2393235

Fairclough, N. (1995). Critical discourse analysis: The critical study of language. London: Longman.

Fairclough, N., \& Wodak, R. (1997). Critical Discourse Analysis. In T. v. Dijk (Ed.), Discourse as Social Interaction. Discourse Studies: A Multidisciplinary Introduction (vol. 2, pp. 258-284). London: Sage.

Milman, A., Li, X., Wang, Y., \& Yu, Q. (2012). Examining the guest experience in themed amusement parks: Preliminary evidence from China. Journal of Vacation Marketing, 18(4), 313-325. https://doi.org/10.1177/1356766712449374

Wodak, R. (1995). Critical Linguistics and Critical Discourse Analysis. In J. Verschueren, J.-O. Östman \& J. Bloomaert (Eds.), Handbook of Pragmatics (pp. 204-210). https://doi.org/10.1075/hop.m.cri1

\section{Copyrights}

Copyright for this article is retained by the author, with first publication rights granted to the journal.

This is an open-access article distributed under the terms and conditions of the Creative Commons Attribution license (http://creativecommons.org/licenses/by/4.0/). 